\title{
Searching Images of Kengtung: An Old Walled City
}

\section{Town}

\author{
Khin Htay
}

Department of History, Taunggyi University of Arts and Science, Southern Shan State, Myanmar

\begin{abstract}
Geopolitically Kengtung region was located in a most strategic place in Myanmar. It shares borders with China on the north and Thailand on the east. Kengtung is a place which forms a significant historical site in the easternmost part of Myanmar. From the geopolitical point of view, the region was located in a most strategic place. Its situation forced to safeguard the region. The town lies on a critical point of Myanmar's defences. The restriction of exacting money as a yearly tribute did not concern for Kengtung. The tradition of paying homage was appeased to the King. The ruling Sawbwa which achieved the valuable return presents of the Burmese King. Kengtung came in the first class, and was the most important of the Myanmar's possessions east of the Thanlwin River. Its position may be roughly judged by the tribute paid to the King and the contigent it was bound to supply to the royal army. Therefore, Kengtung was very important for the security of Myanmar's eastern frontier during the Konbaung period. It was like a small Union within an Empire together with multinational races of Myanmar. A good deed of past events blanket over the town till today.
\end{abstract}

Key words: Glory and greatness of the past, searching historical images, walled city town, outpost town, critical point.

\section{Introduction}

Kengtung falls within the sphere of the influence of Tai racial territory. It is a home of the people Lus, Lems, Hkuns and Laos. This territory stretches from Sipsawng Panna in the north to a point in the Menam valley where the Thais and the Laos call it the boundary between them, and it is bounded in the west by the Salween (Thanlwin) and in the east by the eastern watershed of the Mekong. Kengtung was regarded as an outpost town of Myanmar during the Monarchical time. The town began to be a very prominent town in the time of King Bayinnaung (1550-1581).

\section{Physical Geography of Kengtung}

The town stands in $21^{\circ} 17^{\prime} 48^{\prime \prime}$ north latitude, and about $99^{\circ} 40^{\prime}$ east longitude [1]. It lies between the Thanlwin and the Mekong Rivers, touching both rivers [2]. The total area of Kengtung state is 12,400

Corresponding author: Khin Htay, Ph.D, professor, research field: cultural history. square miles. Kengtung has an area of 2 square miles. It has 2,622 feet above sea level. It falls in eastern Shan State. It is the biggest state among the Shan States [3]. It includes in the division of Khemarattha [4]. Kengtung was recorded as Gon Pyi (Gon State) in Myanmar Chronicle [5]. In Pali, the name of the town is Khemarata Saiya Soti Tung Kapuri. Its classical name is Khemarata Tung Kapuri (Tungaburi). It was placed under the charge of the Khemarata Taing (Province). An account stated that there were sixty-nine Hkun (Gon) families who originally came to settle in Kengtung. The successive rulers of Kengtung were the descendants of the Mangrai family of Chiang Rai [6]. According to the Sittan of 1635 by King Thalun, the area of Gon State was fixed as Kyaw Kathe (Vietnam) in the east; the sea in the south; Laos in the west and twelve pannas in the north respectively [5]. There are thirty two towns in Kengtung state. Geopolitically the location of Kengtung state was very important in the Konbaung Period (1752-1885) because it shares borders with China on the north and Thailand on the east.Its situation encouraged her to be 
gate way for easy access to four different countries. It makes a critical point of Myanmmar's defences [7]. At present, Kengtung State is divided into five sub-state viz: Kengtung, Mong Hkat, Mong Yang, Mong Laar and Mong Peng [3].

\subsection{Brief History of Kengtung}

The city of Kengtung was formerly known as by the names of Damilat, Mong Aung Pu and Sanda Wazi respectively. King Sanda Waziri ruled in there. There was no heir for the throne of Kengtung after the death of King Sanda Waziri. Gawpala was placed on the throne of Sanda Wazi by the Crows. So he became King of Sanda Wazi. Twelve years later the Buddha had appeared, Sanda Wazi was flooded and became a Damilat Lake. Buddha spoke his prediction to Ananda, one of his disciples that a hermit from the northern country will come to this place after his death. A hermit will build a city there. The city shall be populated with three kinds of people. The Buddhist religion shall be flourished in there. Buddha also preached his predictions for the future life of the city. Any aggression will not fall on the city as well as food and provisions shall be abundant [8].

One hundred and fifty years after Lord Buddha's parinivana, four hermits had arrived near the Damilat Lake. They all were the sons of a Chinese King. They began to appear a new city in there. As the King was very mighty and powerful, all other Kings took refuge under him. The four brother hermits had reached the Damilat Lake at the foot of the Loi Sumsak Mountain. The eldest hermit named Tongarathi wished to dry up all the waters from the lake. This dried up basin was chosen to build a new city for their father. The company left China and built a city in this dried up basin. But the new city was left as the people living in that city did not desire to continue to live. They went back to China [8].

Not long after the Chinese had left from the city, Lwas nationalities came to live in there. They chose their leaders and built a city. Mang Yoi was chosen as their chief. He ruled in Waing Keio. There were eight ruling chiefs of the Lwas who separately ruled in eight countries of the Lwas. They ruled with kindness. Seven years later their cities became prosperous cities [8].

\subsection{How Kengtung Came into Existence}

In order to conquer upon the country of Lwas, King Paya Mang Hai (Mang Rai, 1259-1317) of Chiang Rai dispatched an army of five thousand strong armed men under the head of two brother princes to the country of Lwas. The Lwas successfully repulsed the enemies. So they retreated to their land. Next year, King Paya Mang Hai laid down a plan to attack the country of King Mang Yoi and then he continued to attack the other remaining seven Lwas countries. He used the method of sending spy. The two Lwas, who were serving under him, were sent to Waing Keio. The country of Lwas easily fell under the enemy's hands. King Paya Mang Hai had a desire to build a new town in the Damilat valley. His astrologers and learned ministers had chosen Waing Keio which had a good opportunity to contact with all parts of the valley. He built a new town named Kengtung. Then the King built a golden palace in the city and invited the peoples of Hkin. They all were permitted to reside in the city. Paya Nam Htong was appointed as a governor to rule the country of Damilat Lwas. The city became a prosperous city. On hearing the news of the flourishing city, the King of China demanded tribute from Paya Nam Htong. The Chinese assumed that the Damilat was first possessed by the Chinese. Paya Nam Htong refused to accept it. So the King of China dispatched a very large army to attack Kengtung. The Chinese army retreated with failure [9].

The Lwas possessed the Kengtung country till the year 1229 AD. Mang Rai (Paya Mang Hai) first came to it in 1230 A.D. and he conquered the Lwas in 1243. He sent Mang Kun (Paya Nam Htong) to the Kengtung state in 1243. Mang Kyin succeeded and ruled till 1253 A.D. Mang Rai (Paya Mang Hai) sent 
his son and a pongyi (monk) there in 1253. They ruled together the State till the year 1264 A.D. Sao Nam Nam succeeded and ruled the State in 1264. His reign lasted 53 years. In 1317, Sao Hsam Mun Hwe ruled for seven years. In 1324, Sao Lak ruled for eighteen years. In 1342, Sao Hsai Nan ruled for eighteen years to 1360 [10].

The chronicle of Kengtung gives the founding of Kengtung and its successive Chiefs in order. The Chinese were the first people who came to settle in
Kengtung area. The Lwas came to live in Kengtung in the tenth Century A.D. after the Chinese. They had tried to occupy Kengtung as they assumed that they were the first possessor of Kengtung. The Gon people began to enter in this place in 13th century AD. The Sawbwa began to rule in 1253. Myanmar began to expand their eastern territory after 1557 . Kengtung came in Myanmar's hand in 1581 [3]. There were forty one Chiefs who ruled in Kengtung from 1243-1947 (Table 1).

Table 1 List of Kengtung Chiefs (1243-1947).

\begin{tabular}{|c|c|c|c|c|}
\hline $\begin{array}{l}\text { Sr. } \\
\text { No. }\end{array}$ & Kengtung Chiefs & Reign & \multicolumn{2}{|l|}{ Remark } \\
\hline 1 & Mang Kun & A.D. $1243-1247$ & \multirow{8}{*}{\multicolumn{2}{|c|}{ Delegates of Mang Rai, founder of Kengtung State }} \\
\hline 2 & Mang Kyin & A.D. $1247-1253$ & & \\
\hline 3 & $\begin{array}{l}\text { Sao Nam Taung, a son of Mang Rai } \\
\text { with a monk in joint charge }\end{array}$ & A.D. $1253-1264$ & & \\
\hline 4 & Sao Nam Nam & A.D.1264-1317 & & \\
\hline 5 & Sao Hsam Mun Hwe & A.D.1317-1324 & & \\
\hline 6 & Sao Lak & A.D.1324-1342 & & \\
\hline 7 & Sao Hsai Nan & A.D. $1342-1360$ & & \\
\hline 8 & Sawbwa Yu (Sao Yu) & A.D. $1360-1370$ & & \\
\hline 9 & Sao Sit Pan Tu & A.D.1370-1387 & \multirow{2}{*}{\multicolumn{2}{|c|}{ A native of Chieng Mai, brought to Kengtung by Sawbwa }} \\
\hline 10 & Sao Ai Awn & A.D. $1387-1390$ & & \\
\hline 11 & Sao Ai Wun Hsu & A.D.1390-1403 & \multirow{3}{*}{\multicolumn{2}{|c|}{ Sons of Sao Sit Pan Tu }} \\
\hline 12 & Sao Yi Hkam Hka & A.D. $1403-1416$ & & \\
\hline 13 & Sao Hsam & A.D.1416-1441 & & \\
\hline 14 & Sao Hsam Sili & A.D.1441-1456 & \multicolumn{2}{|l|}{ Son of Sao Hsam } \\
\hline 15 & Hpaya Ai Lao Hkam & A.D.1456-1474 & \multicolumn{2}{|l|}{ Leaving five sons } \\
\hline 16 & Sao Ai Lao & A.D.1474-1501 & \multirow{2}{*}{\multicolumn{2}{|c|}{ Hpaya Atita Raza in title, son of Hpaya Ai Lao Hkam }} \\
\hline 17 & Sao Naw Kiao & A.D.1501- & & \\
\hline 18 & Sao Hsai Kaw & No Date & \multirow[t]{2}{*}{ Unpopular man } & Sons of Hpaya Ai Lao \\
\hline 19 & Sao Hsai Pawm & No Date & & Hkam. They ruled in turn. \\
\hline 20 & Sao Hsam & No Date & Disliked by the people & No precise dates to them. \\
\hline 21 & Sao Hkam Mu & No Date & \multicolumn{2}{|l|}{ Unpopular man } \\
\hline 22 & Hpaya Kiao Yot Fa Narenta & A.D. $1523-1560$ & \multicolumn{2}{|c|}{ A monk called to rule } \\
\hline 23 & Sao Mong Hka & A.D. $1560-1598$ & \multicolumn{2}{|c|}{$\begin{array}{l}\text { Hpaya Ratana Pumminta Narinta } \\
\text { in title, son of Hpaya Kiao Yot Fa Narenta }\end{array}$} \\
\hline 24 & Sao Hkam Tao & A.D. $1598-1620$ & \multicolumn{2}{|c|}{ Sutana Raza in Title, son of Sao Mong Hka } \\
\hline 25 & Sao Mong Hkak & A.D. $1620-1637$ & \multicolumn{2}{|c|}{ Hpaya Kiao Pap Narinta in title, son of Sao Mong Hka. } \\
\hline 26 & Sao Un & A.D. $1637-1650$ & \multicolumn{2}{|l|}{ Atita Raza in title } \\
\hline 27 & Sao In Hkam & No Date & & \\
\hline 28 & Sao Awk & No Date & \multicolumn{2}{|l|}{ Known as Hsurinta Raza } \\
\hline 29 & Sao Mong Lek & No Date & \multicolumn{2}{|l|}{ Son of Sao Mong Hkak } \\
\hline 30 & Sao Hsam Hpi & No Date & & \\
\hline 31 & Sao Mong Hkawn & A.D. $1730-1740$ & \multicolumn{2}{|l|}{ Known as Maung Nyo } \\
\hline 32 & Sao Mong Hsam & A.D. $1742-1786$ & \multicolumn{2}{|c|}{ Pommin Ta Narin Ta in title } \\
\hline 33 & Sao Kawng Tai & A.D. $1787-1802$ & \multicolumn{2}{|c|}{ Siamese (Thai) invasion started in 1802.} \\
\hline
\end{tabular}


Table 1 to be continued

\begin{tabular}{llll}
\hline 34 & Sao Maha Hkanan & A.D.1813-1857 & $\begin{array}{l}\text { He founded the present town of Kengtung in 1819. The } \\
\text { walls were completed in 1833. } \\
\text { Son of Sao Maha Hkanan } \\
\text { Son of Sao Maha Hkanan }\end{array}$ \\
36 & $\begin{array}{l}\text { Sao Maha Pawm } \\
\text { Sao Hseng }\end{array}$ & $\begin{array}{l}\text { A.D.1858-1876 } \\
\text { A.D.1876-1881 }\end{array}$ & $\begin{array}{l}\text { Son of Sao Maha Hkanan. Burmese authority over } \\
\text { Kengtung ceased in 1882. }\end{array}$ \\
38 & Sao Kawng Tai & A.D.1881-1885 & $\begin{array}{l}\text { The eldest son of Sao Kawng Tai (1881-1885The British } \\
\text { Government took over Kengtung in 1890. } \\
\text { Son of Sao Kawng Tai (1), appointed Sawbwa by the } \\
\text { British Government }\end{array}$ \\
49 & Sao Hkam Hpu & A.D.1886-1895 & $\begin{array}{l}\text { The eldest son of Sao Kawng Kiao Intaleng. After 1937 } \\
\text { Captain V.G. Robert, Officer of Burma Frontier Service, } \\
\text { ruled Kengtung State. } \\
\text { Son of Sao Kawng Tai (May 1937-Oct.1937) }\end{array}$ \\
\hline
\end{tabular}

Source: (a) Scott, J. George., and Hardiman, J.P. 1901. Gazetteer of Upper Burma and The Shan State, Part 2. Vol.1. Rangoon: Superintendent Government Printing: 402-12.

(b) Than Tun. 2004. Nal Hlai Yazawin (Collecting historical data from different lands), Yangon: Pyi Zone Publishing House: $39-41$.

(c) List of Chiefs and Leading Families in the Shan States and Karenni. 1943. Simla: Government of India Press: 5-6.

\subsection{Population}

It will be seen that the population of Kengtung is sharply divided into two classes; the Shans, inhabitants of the valleys, and the various hill tribes which occupy the mountainous parts of the state. Of the former there are three distinct varieties. They are:

(1) The Tai or Western Shan, near the Salween or as a settler, in other parts.

(2) The Hkon, the inhabitants of Kengtung valley.

(3) The $\mathrm{Lu}$ of the valleys east of Kengtung lying towards the Mekhong.

These three races of Shans of course intermingle and overlap [10].

In the historical notes an account is given of the supposed seat of the Hkun before they colonized Kengtung. The Hkun population is settled in a comparatively small and compact area in the centre of the state, while the Lu occupy all the eastern valleys towards the Mekhong, and the Tai the western portion of the State. It seems probable that the total Shan population is made up of about equal numbers of the three races [10].

In the capital town the population is, as might be expected, very mixed. Hkun preponderate, but there are considerable numbers of $\mathrm{Lu}$ and Western Shans, as well as some Lao. There is also a fairly large community of Burmans, or persons of Burmese descent, sometimes pure, but more often of mixed parentage. The Shan-Chinese do not live within the city, but their largest village adjoins the eastern wall, and they have several others in the valley [10].

\section{The Founding of Walled City Town}

The town is built on low undulating ground. A dry ditch and a brick wall surround it. The older part of the wall is rather ruinous, but the more recently built portion enclosing the southern half of the town is in better preservation. The walls are measured about five miles round [10]. Actually, the walls are measured $4 \frac{3}{4}$ miles ( 4 miles and 6 furlong) round and have 12 gates.

There are nine nawngs, or swamps, within the walls, and several swamps are rich outside the walls. Wells sunk at the edges of these swamps furnish the water-supply, and the population is most densely around the swamps [10]. The nine swamps are listed as follows:

(1) Nawng Tung;

(2) Nawng Yae;

(3) Nawng Yang;

(4) Nawng Tha Chang;

(5) Nawng Kon;

(6) Nawng Khai; 
(7) Nawng Pong;

(8) Nawng Khae and;

(9) Nawng Pha [11].

The position of the town has been chosen with great skill, and the wall and the parapet which surround it are led along the crests of the low sloping hills amongst which it is built. The splendid parapet and ditch are ascribed by the Burmese to Alaungpaya. Viewed from outside, the parapet in most parts is scarcely visible, the earth from the deep V-shaped ditch having been thrown out almost as much on the glacis as on the parapet. Wall and parapet together stand up about ten feet above the level of glacis. The wall is two feet thick and from four to six feet high on the inside face. It is built of small burnt bricks, but is much ruined in parts. The summit of the wall is castellated and loopholed at four feet intervals; the parapet on which the wall stands is ten feet thick at the top [10].

The ditch is the most formidable part of the defences; it is $\mathrm{V}$-shaped and 25 feet deep with very steep sides. The ditch is thirty feet broad at the top without any water in it; at several points there is a break in the ditch, but these parts are covered by marches. At each gate way an earth causeway crosses the ditch. There are no bastions; but the skilful manner in which the parapet curves backwards and forwards, following the crests of the undulating low hills [10].

The fort stands on high ground at the foot of the range of hills. The wall on the southern face has been lately extended, in consequence of an order from Ava (Inwa), directing that all Sawbwas shall surround their capitals with walls 6,000 cubits in circumference. The wall, which is about 15 feet high including the parapet, consists of a double wall of brick and mud of about two feet thick, with the space between them filled up with earth. In many places, the weight of the earth during the rains has brought down portions of the wall, and parties of Chinamen are at work repairing these breaches, the inhabitants paying them for their labour. This industrious race furnishes the only artisans in the place. Many of them come in search of work during the dry season, and after collecting a little money together they return to their homes. The fort has twelve gates, four or five of which are on the eastern face, but it has no bastions or embrasures for cannon. The wall, following the conformation of the ground, presents a most irregular fortification. Swamps supply the place of a ditch, and where these do not exist, a cutting has been made in some places to the depth of 30 feet from the foot of the wall through the hilly ground to a level with the swamps, but no water enters it [1].

The present wall (Figs. 1-2) was renovated by Sao Maha Hkanan (1813-1857) in 1819 and it was completed in 1833 [10]. The twelve city gates (Figs. 3-15) are listed as follows:

(1) Par Leng City Gate;

(2) Keng Lan City Gate;

(3) Ngarm Hpat City Gate;

(4) Seng Meng City Gate;

(5) Hpar Yang City Gate;

(6) Mingala City Gate;

(7) Kai Haik City Gate;

(8) Yang Bueng City Gate;

(9) Naung Hpar City Gate;

(10) Naung Late City Gate;

(11) Yang Kham City Gate;

(12) Yang Kong City Gate [11].

Near the centre of the enclosure is the Chief's Haw, or Palace (Figs. 16- 17). It is a comparatively new building (having been completed about 1892) of good timber walling, the roof of tiles, supported by fine chestnut and in-gyin posts. There is a central audience hall with a throne at its upper end, reached by doors from behind. The living rooms of the Chief's wives occupy more or less detached portions of the building. A brick wall encloses the compound, to which there are two entrance gates. The state court-house adjoins the residence of the chief [10].

The whole compound of the palace was surrounded by a brick and mud wall of eight feet high. The palace itself, a shabby looking pile of wood, raised about fifteen feet from the ground, on high pillars. The 


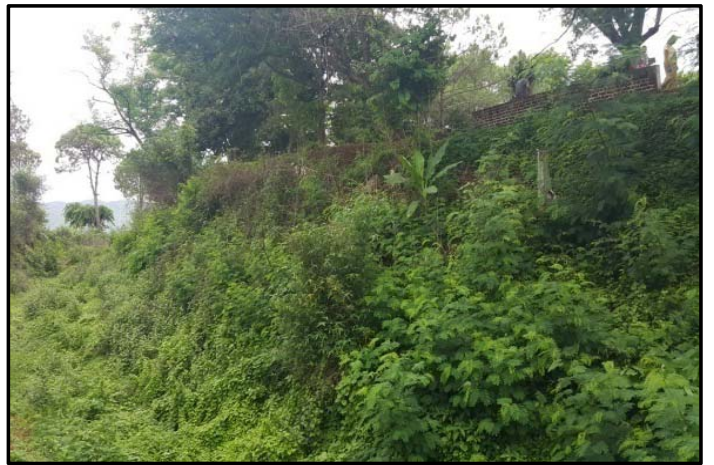

Fig. 1 Kengtung City Wall.

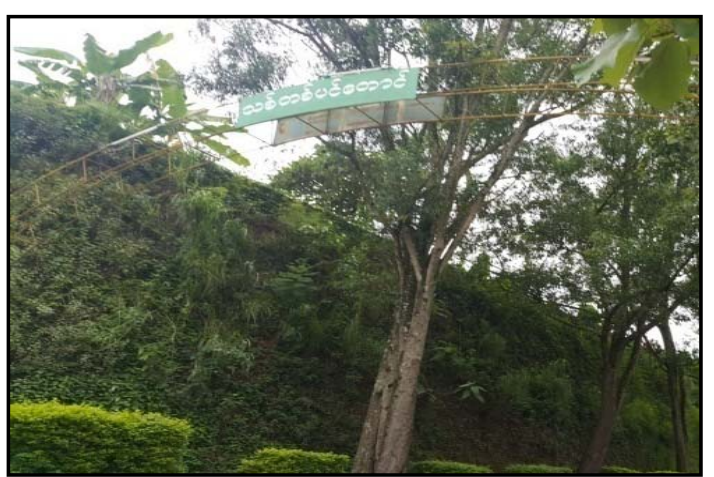

Fig. 2 Kengtung City Wall.

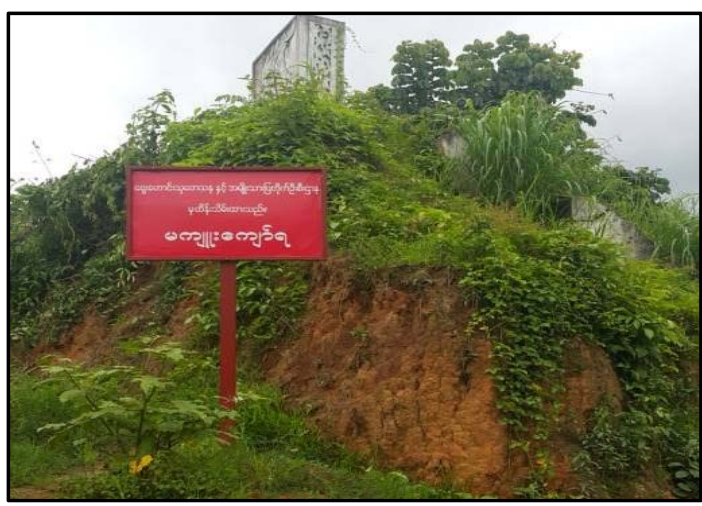

Fig. 3 Mingala City Gate \& Wall.

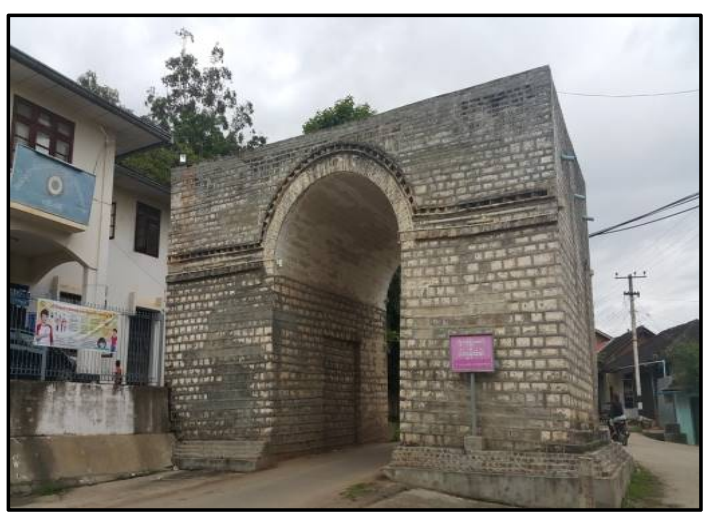

Fig. 4 Par Leng City Gate.

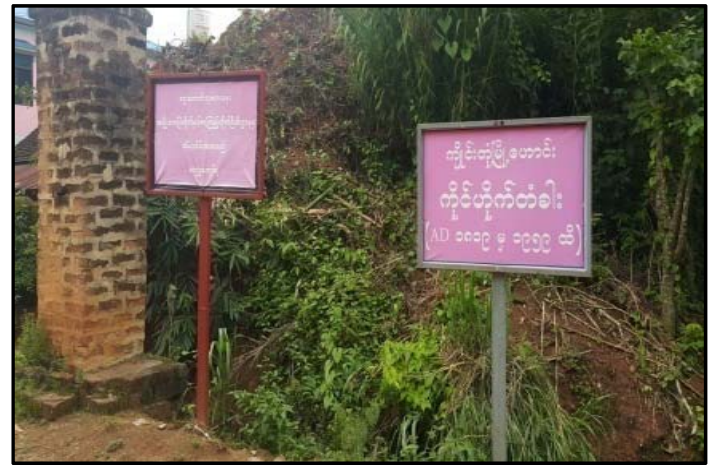

Fig. 5 Kai Haik City Gate \& Wall.

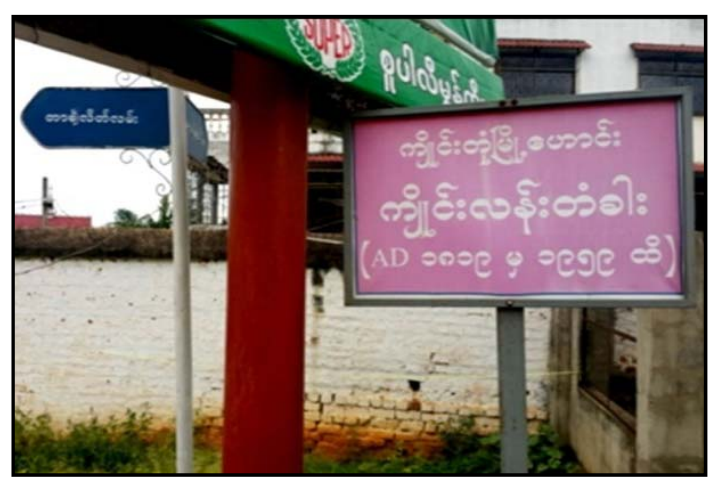

Fig. 6 Keng Lan City Gate.

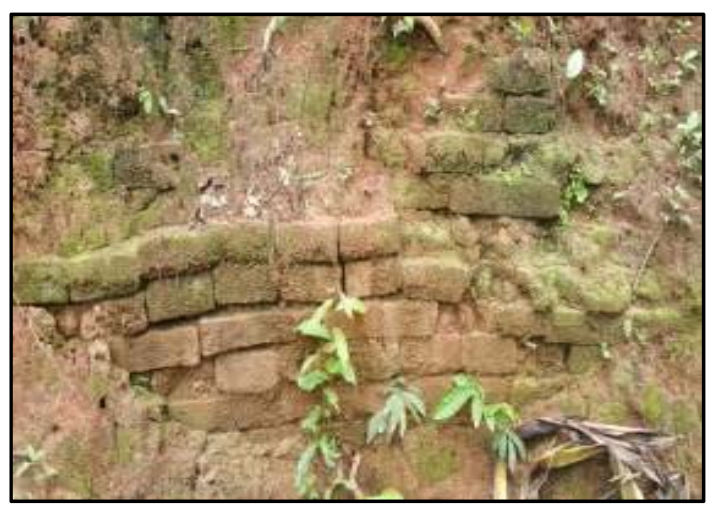

Fig. 7 Yang Kham City Gate \& Wall.

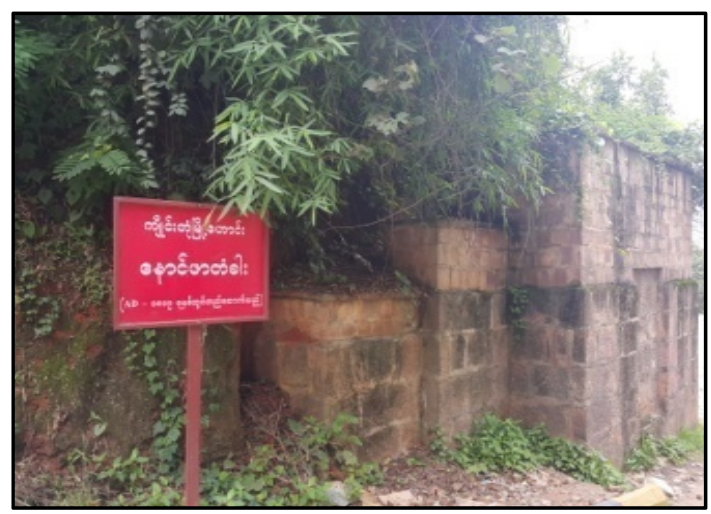

Fig. 8 Naung Hpar City Gate. 


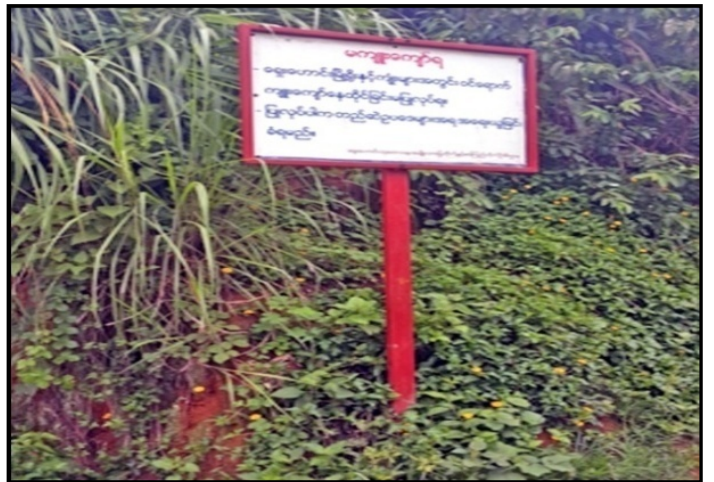

Fig. 9 Yang Kham City Gate \& Wall.

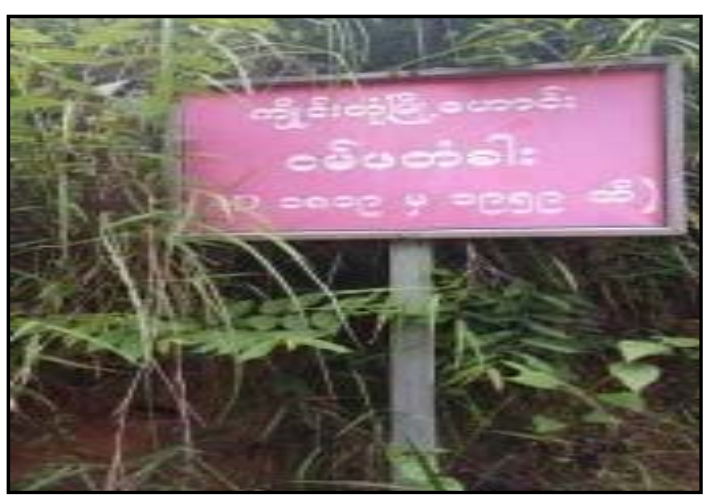

Fig. 10 Ngarm Hpat City Gate \& Wall.

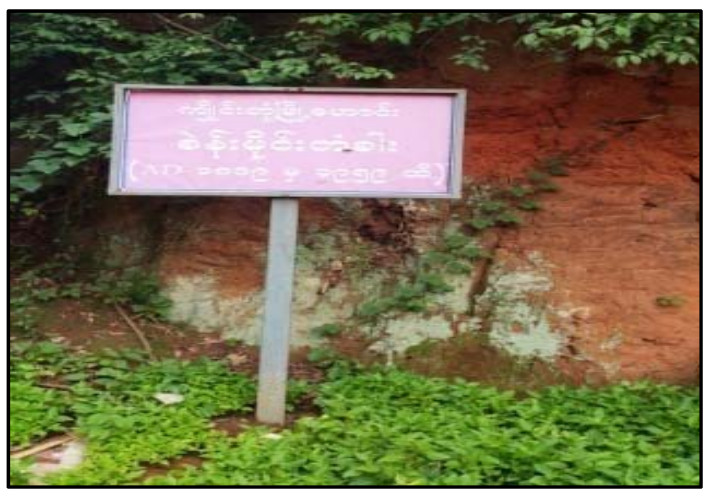

Fig. 11 Seng Meng City Gate \& Wall.

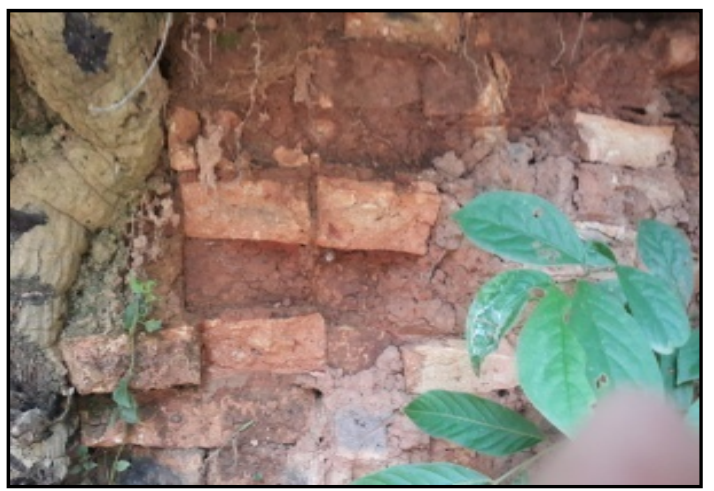

Fig.12 Ngarm Hpat City Wall.

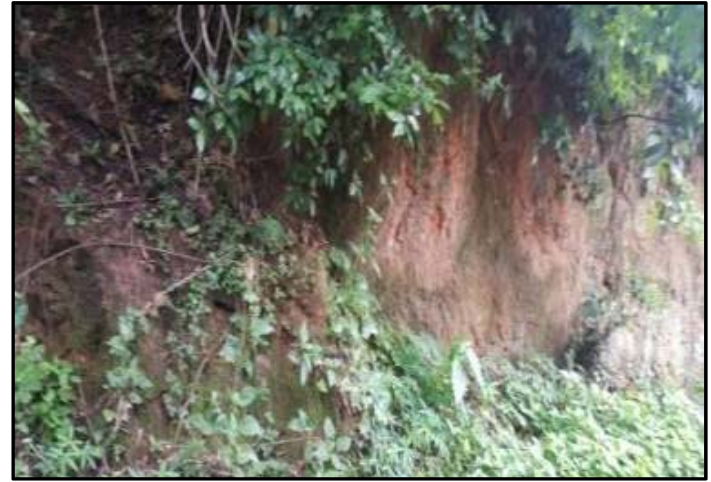

Fig. 13 Naung Late City Wall.

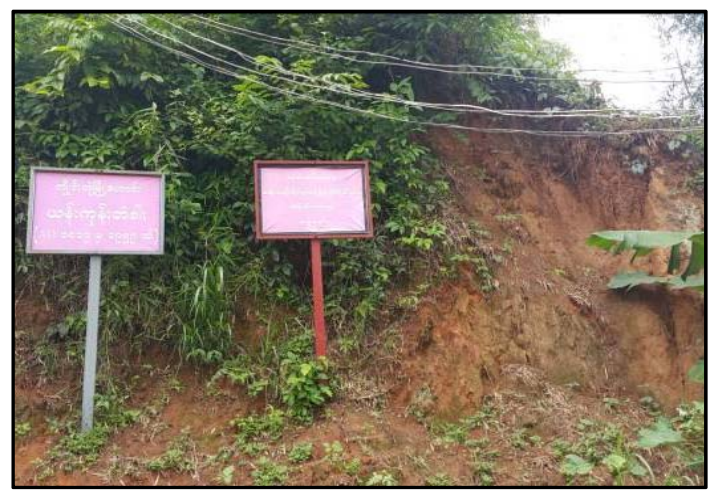

Fig. 14 Yang Kong City Gate \& Wall.

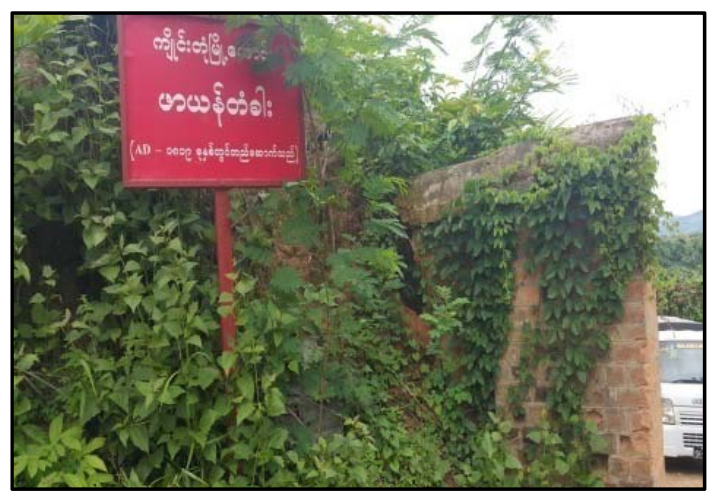

Fig. 15 Hpar Yang City Gate \& Wall.

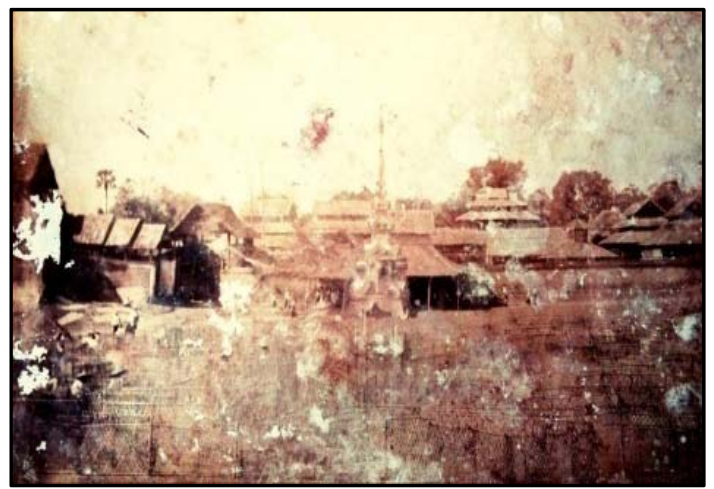

Fig. 16 Kengtung Haw (Old). 


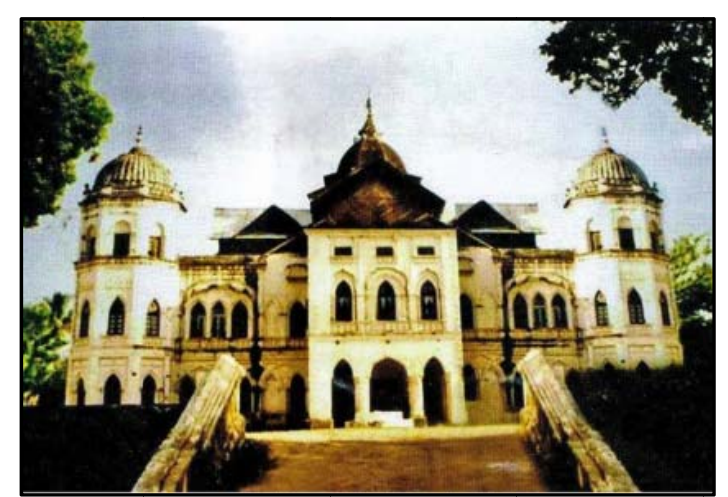

Fig. 17 Kengtung Haw (New in 1906).

carpets had been spread in front of the Sawbwa's seat. The interior of the building was very richly gilt, forming a strong contrast with its exterior. The throne stood at one end within a railing, very elegantly carved and gilt, with two white umbrellas on each side of it [10].

The sawbwa, however, was seated on a handsome low gilt couch in front of the throne, surrounded by a number of men holding swords in gold scabbards at a respectful distance. His two eldest sons and nephew were seated on the ground on his right, and the officers ranged in lines on each side in front. Though many sawbwas are permitted to have thrones, white umbrellas, and other emblems of royalty, yet they cannot make use of them personally [10].

Although there were twelve Haws, or Residence, within the walls, only five Haws can be found in present time. They are Sum Mon Haw, Keng San Haw, Nan Wun Yone Haw, Kiao Sai Meng Haw and Keng Kaung Haw. The first Sum Mon Haw facing south was the residence of Sawbwa Sao Hsai Long, the last Sawbwa of Kengtung (Fig. 18). It is a single-storey brick building. It is situated on the Sum Mon Hill. The second Keng San Haw near Ho Kat Monastery was the residence of Keng San Sawbwa. It is two-storeyed brick building facing towards the southern side. The third Haw is Nan Wun Yone Haw. It was the name of a Queen of Sawbwa Sao Kawng Kiao Intaleng. It is faced on southern side. It is a two-storeyed brick building. The fourth Haw facing eastward is known to be Kiao Sai Meng Haw. It is two-storeyed brick

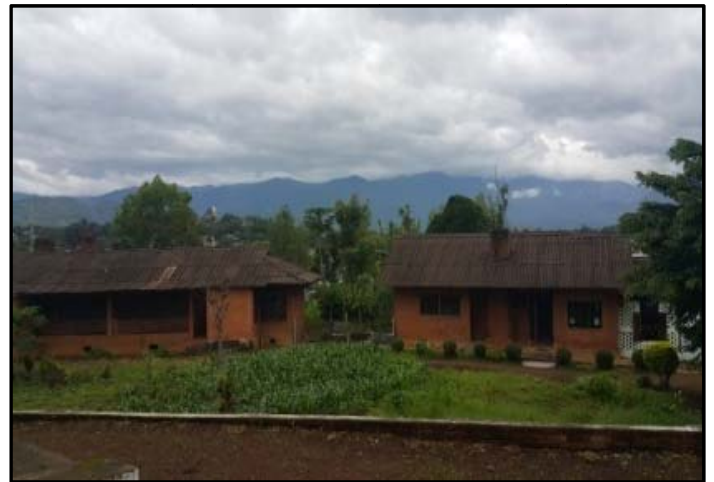

Fig. 18 Sao Hsai Long's Haw.

building. The last Haw is Keng Kaung Haw. Keng Kaung Sawbwa Kiao Yuat Meng had lived in this Haw. It faces south and it is a single-storey brick building in U-Soat quarter, Kengtung. The temporary Haw of Sawbwa Kiao Yuat Meng is still left in the compound of Keng Kaung Haw [11].

Theoretically full power is vested to the Sawbwa. $\mathrm{He}$ is however, far from being an absolute ruler. Neglect of advice from his ministers and from the Buddhist priests, or gross violations of old established custom, has always been held to justify the deposition and even murder of a chief. His real personal power depends, to a great extent, on his force of character and energy. The administration is in the hands of the chiefs, assisted by a Council of Ministers. Above these ministers is the Kyemmong or Heir Apparent, but he is supposed to act within the council, though taking precedence of all its members, and enjoying a rank second only to that of the ruling chief. Next to the Kyemmongcomes the Prime Minister [10].

During the British colonial period, Kengtung was placed under the Southern Shan States and its borders became fixed. In October 1937, Sao Kawng Tai was murdered by his nephew Sao Hsi Ha. On his death the state was placed in the charge of an administrator, Captain V. G. Robert, an officer of the Burma Frontier Service. When the state was occupied by the Japanese in 1942, Sao Boon Wart, a son of the Sawbwa, Sao Kawng Kiao Intaleng by his 5th wife Sao Nang Yong was appointed administrator by the Japanese [12]. 


\subsection{The Administration of Kengtung}

During the reign of Sawbwa Sao Sae Pawn (1523-1524), Chieng Mai invaded Kengtung. Kengtung Sawbwa Sao Sae Pawn fled into the Chinese territory [3]. In 1557, Sawbwa of Mong Nai, Nyaung Shwe and the Chiefs of Yatsauk and Naung Mon rebelled against the Myanmar's throne depending upon Chieng Mai, Kengtung, Keng Yone and Hsenwi(Theinni) [13]. Therefore, Kengtung closely associated with Myanmar. After conquering upon the Myanmar's eastern areas by King Bayinnaung, Chieng Mai fell under him in 1558 [14]. With the support of Kengtung Sawbwa, Myanmar advanced Thailand in 1568, Kengtung Sawbwa furnished with 100 elephants, 1,000 horses and 10,000 men for military expedition [14]. Kengtung Sawbwas joined hands with Myanmar throughout the period of hostile relations between Myanmar and Thailand. Therefore Myanmar King sent ten elephants as a present to Kengtung Sawbwa in 1576 [3]. In 1582, Kengtung Sawbwa also helped the Myanmar King's forces in attacking Chieng Mai [10].

Sometime Kengtung became a place of taking refuge by the rebels and on the other hand it was the only gate way to enter into the Myanmar Empire by the invaders.This point was supported by the significant events of Thai invasion into Kengtung in 1600 [3] and the rebellion of Mong Nai Sawbwa to the Myanmar's throne in 1614. The rebel Sawbwa took refuge in Kengtung [15]. Therefore Myanmar King sent 150 elephants, 1,500 horses and 40,000 men to Kengtung to suppress the rebel Sawbwa in 1621 [15]. And then Myanmar troops continued to advance Keng Yone, closing with China, and camped at Keng Saeng [16].

The martial clashes sometime occurred between Myanmar Kings and the Sawbwas of Kengtung.For instance, in the time of Sawbwa Sao Hsam Hpi (1702-1708) Myanmar forces attacked Kengtung in 1708 [15]. In 1742, Sao Mong Hsam (1742-1786) ruled the state of Kengtung. At the time of peace a good relationship between the two Monarchs of Myanmar and China had been reached. For example, Chinese envoys arrived Kengtungon July 31,1755 [17].

The present ruling family traces their descent to Sao Mong Hsam, who was recognized as Sawbwa by the Myanmar's court in 1742, and ruled till 1786. He was a good ruler and was much respected. During his time, the state was involved in war with China and the Chinese Shan States, as a subordinate ally of Myanmar, and suffered considerably [10, 12]. At that time, a garrison was placed at Kengtung and the Myanmar army returned to Ava (Inwa) [10]. Sao Mong Hsam was succeeded by his son Kawng Tai (1787-1804) [12].

In 1802, the first of the three great Thai invasions started. The State was terribly ravaged; Kengtung town was taken and sacked, many families were carried away and made to settle in Northern Thailand. Sao Maha Khanan was the only member of the ruling family to escape. For some years, he maintained himself and obtained his recognition by the Court at Ava (Inwa), he regained the State and ruled from 1813 to 1857 [12]. He died in 1857 [12].

Sao Maha Khanan is the most striking figure for the defence of the State. He successfully repulsed the great Thai invasions of 1852 and 1854. He restored and enlarged the old walled city. His eldest son Maha Pawm succeeded to the State and ruled for eighteen years. Maha Pawm was followed by his brother Sao Hseng (1876-1881). SaoHseng was succeeded by his brother Sao Kawng Tai (1881-1886). All these Chiefs like their father Maha Khanan were formally recognized by the Court of Ava (Inwa) [12].

A Myanmar official with a small garrison was kept at Kengtung, no tribute was imposed, but homage offerings of gold and silver flowers were sent yearly to Ava (Inwa), and presents frequently of great value, were received in return. The suzerainty in fact was of a mild in character. Finally, it came to an end in 1882. In the same year, Mong Nai Sawbwa rebelled against 
the Myanmar's throne and took refuge in Kengtung. So the Myanmar officers continued to reside at Kengtung [10, 12]. Shortly after his accession, Sao Kawng Tai sent a force to attack the Sipsawng Panna. And then he also sent another force to attack Mong Lom (?Mong Lem) [10].

Relating to the unrest political situation of the east of the Thanlwin River area like Mong Hli, Keng Chaing, Keng Hsi and Kengtung, etc., a Commander of Mong Nai force was appointed to solve the unrest situation of those areas. He was given the strength as follows:

(1) 100 men of gold lance;

(2) 100 men of Viengcheng guns;

(3) 50 men of silver swords;

(4) 50 men of silver lances;

(5) 50 men of hkan sut group horses;

(6) 150 guns of manufactured in royal arsenal;

(7) 75 viss of gun powder;

(8) 7,500 bullet balls and;

(9) 450 flat pieces of flint [4].

He had to carry out a thorough investigation about all things happening there and report to the capital city [4]. Furthermore, the King strictly issued an order on military affairs of those regions. The commander of Mong Nai forces was instructed to carry out the following important four things:

(1) To pay attentiona military affair requires either at night or in the day time but to find the cause of it before any measure is taken.

(2) To give orders precisely on what they have to do for synchrony and efficiency.

(3) To keep all men in good morale and all weapons in good condition and

(4) To issue enough ammunitions but allow no waste [4].

At the time of political weakness faced by central government, the opposition of defiant group was easy to influence over the Myanmar's suzerainty. In this situationthe, Limbin prince came to Kengtung in 1881 and the Limbin Confederacy was formed. The
Sawbwasof Mong Nai and Lawk Sawk (Yat Sauk), and the Town Officer of Mong Nawng raised forces in Kengtung and recovered their states [10]. In 1882, Kengtung Sawbwa Sao Kawng Tai (1881-1885) killed the Myanmar general and 30 followers at Kengtung. He then went to Keng Yone and disrupted in there [18].

The past attitude of Kengtung would be checked.Kengtung also revolted against the Myanmar's throne in 1709 [3]. Kengtung Sawbwa seized the Myanmar Resident and his escort. And then he attacked and seized Keng Chaing, east of the Mekong. He installed a chief in Keng Chaing by his own will. As soon as Keng Chaing was seized by Kengtung Sawbwa, a force was sent to Kengtung by the Chinese general to take action on Kengtung. After the Chinese Commander had settled these events, the authority of the Burmese (Myanmar) Government failed to exist in Kengtung [2].

Soon after Thibaw's accession to the throne, many of the Shan States revolted against him, and Kengtung took a conspicuous part in the rebellion[2]. In 1882, the Sawbwa of Mong Nai and the Chiefs of several neighbouring States revolted against King Thibaw (1878-1885) and took refuge in Kengtung [2, 19]. After this event, Myanmar's rule ceased in Kengtung. On the collapse of Myanmar's authority in Kengtung, the Regimental Officer of Mong Yu withdrew from there, with the intention of going back to Mandalay [10].

In 1886, Sao Hkam Hpu, eldest son of Sao Kawng Tai, succeeded to the Sawbwaship. In 1890, the British Government took over Kengtung. In 1896, Sao Kawng Kiao Intaleng (1897), brother of Sao Hkam Hpu, was appointed as Sawbwa by the British Government [10].

\subsection{The Arrangements for Security of Kengtung}

To maintain the political situations of the regions east of the Thanlwin River and to safeguard the regions peacefully, the central government supported 
fairly arrangements for security of those regions. The guard stations were placed at the ferries of east of the Thanlwin River. Each gate was filled with 50 or 60 men to guard those regions. In Kengtung town, the arrangements for security were made as well. The Sawbwa of Kengtung supported arms and ammunitions to Mong Nai Sawbwa. At Mong Pye, there were 500 men to guard the town [19].

At the strategic places, the frontier guards were stationed. In the Shan States, the frontier guard was called "Htar". There were at least 10 armed men to guard the outpost. The two were gunners and the rest eight were spearmen. All the armed men were under the direct control of a minister called Kin Sin Wun (Officer of guard stations). The officers for the guard stations were selected and appointed by the Hluttaw (Administrative Body). According to the Royal Order of 28 August 1787, a Burmese general was instructed to enlist the help of local chiefs and to make a stand at Mong Nai-Mong Pang and enlist the help of Cis-Salween Chiefs mostly to get provinces for garrison. They were responsible to control all ferries, toll gates and guard stations along the Salween (Thanlwin) River and in all the gateways to trans-Salween places [20].

Burmese generals were assigned to proceed to Mong Nai-Mong Pang to shut and stop (asee-ahso) the enemy advance and put up a strong defense at Mong Nai-Mong Pang with all available men of Cis-Salween area. They had to guard all routes from trans-Salween area and get all provisions stored at Mong Pang to keep their men on alert for twenty four hours. This order was passed on 23 March 1788 [20]. The arms and ammunitions were given to support if necessary [20].

In order to defend the State, Burmese Ministers had to go to Mong Nai and Mong Pang and made a strong stand there after enlisting men and material help from chiefs of Cis-Salween area. They had to blockade all ways coming from trans-Salween. This order was passed on 1 April 1788 [20].
According to the Royal Order of 3 April 1788, the troops stationed at Mong Nai and Mong Pang had to send any important report by mounted couriers [20]. There were over 100 armed men at Mong Sat but there were 76 armed men left behind at Mong Hsat. Therefore the Chiefs of Myay Lat (Cis-Salween Area) had to supply the missing men. This was passed on 3 August 1795 [20].

For the security of the trans-Salween areas, the King passed an order to Hsenwi Sawbwa on 1 November 1806 to post his men at all ferries, guard house and toll gates to check the Shan, Chinese and Burmese traders' crossing over to the east bank of Salween River. They were not allowed to take any gun [20].

The security arrangements were critical points to keep the frontier areas especially the eastern areas centered at Kengtung which fall on Alan U Kin Wa (Fronier Areas), Burmese Kings took great care to keep the fourteen Htar (Outposts) were strongly based along the Salween River. As a result, there was peace in their territory [21]. The same name Kan: was used for both a toll station where dues on suitable goods in transit were collected and a guard station where at least ten armed men under one leader were on defense duty [22].

The palace, capital city, seaport, frontier town, garrison town, guard station, etc. had always some armed men for defence and under certain conditions a royal order would be passed to strengthen the defences. More sodiers than it was necessary in a normal condition would be sent to a cerain town.

Town Guards (Mrui Con Tap) would have local recruits at the rate of one man from every fifty houses [22]. They had to take the following duties.

(1) to intercept an invasion;

(2) to drive away the invader;

(3) to suppress a rebellion in an area;

(4) to watch and stay any of the invasion.

The three district seats of Burmese administration in Shan States were stationed at Mong Nai, Mobye 
and Theinni. Usually, the Shan States were administered by the royal government through Sawbwa, Myosa and Ngwehkunhmu under the surveillance of Myanmar official stationed at their capitals. The Myanmar officials stationed in those garrisons were called Sitkedawgyi, who have several officers under him. The Sitkedawgyi was the deputy of the Bohmumintha (Prince Commander) [23].

The Burmese garrisons were separately stationed at the towns of Keng Hung (Kyaing Yone), Kengtung, Keng Saeng, Mong Hli where Burmese powerfully overwhelmed. But the Burmese power declined in the reign of King Thibaw. Under these circumstances, the regions east of the Mekong River were free from the control of Myanmar's suzerainty. On the other hand, Burmese suzerainty over the regions west of the Thanlwin River was declined.

The State was bound to furnish 5,000 armed men to the royal army. The Kengtung Chief was then excused on the ground that all his troops were required to watch the frontier of Thailand. Kengtung men were not called away for service beyond their own State or borders [10].

Kengtung was regarded as a place of ending Myanmar's land and its flag [5]. Keng Hung and Kengtung were very important towns in Konbaung period. The State furnished a contingent of 2,500 men, half musketeers and half spearmen, and maintained seven posts on the southern frontier from 60 to 100 men [2]. Kengtung contingent was of the same strength; but seven guards, with garrisons of from 50 to 200 men, had to be maintained by Kengtung on the southern frontier [2]. According to the Royal Order of 27 April 1604, the King sent an army of 10,000 fighting men to the north and north east where the people of Shan, Yun, Lu, Tayok and Tayet were living and they rebelled against the Myanmar's throne. They lived close to but on the other side of the Myanmar frontier and at that moment they came to the Myanmar said for loot and plunder. Some wanted to settle in the Myanmar's territories [16].
The number of fighting men recruited by Myanmar King was much less than the recruitment of the Shan Sawbwas. If Myanmar King recruited 1,000 men, the Sawbwa of Shan State could recruit 2,500 men from his land. So, Myanmar Kings paid attention to the affairs of the Shan State [3]. Myanmar King sent 66 regiments with 4,000 horses and 45,000 men to the regions, east of the Thanlwin River to restore law and order of those regions in 1787 [24]. On 21 January 1807, the King instructed to the Mong Nai column that they were not allowed to come back to their land instead they were instructed to continue to march to the towns like Keng Saeng, Kengtung, Mong Nawng and Keng Chiang for security of those regions [25].

For security reason, the guard stations from the golden city to Mong Nai and Kengtung were placed by the King. In 1827, the King placed guard stations (Table 2) at the areas in the east of the Thanlwin River and filled with required gun men (Table 3 ) for security of those areas. The ratio of man and gun is $2: 1$, that is two men can be granted one gun only. In 1850, 1,000 men were recruited from Dala and Thanlyin for Kengtung guard station [26].

Myanmar King paid much attention to the affairs of Myanmar's eastern frontier. For instance, a Royal Order of 10 January 1830 clearly stated that Saw Hkam Ohm was appointed as a Chief of Mong Hli, on the east of the Kingdom. Nga Yi Mun, ex-monk rebelled in Mong Hli. The King ordered that the rebellion was to be suppressed and the leader was to be executed so that all Shan places of Kambhoja (Mong Nai, Nyanung Shwe and Lai Hka), Khemarattha (Kengtung), Zotinagara (Keng Hung) and Sirirattha (Hsenwi) would be peaceful [4].

On 4 May 1837, Myanmar King issued an order regarding the affairs of the areas on the east of the Thanlwin River. The towns of those areas like Mong Hli (Mong Li), Keng Chiang, Keng Hsi and Kengtung etc., made a rebellion. Moreover Chieng Mai was in a state of unrest too [4]. In order to control the unrest political situations of those areas on the east of the 
Table 2 The list of guard stations in 1827.

\begin{tabular}{lllll}
\hline No. & Names of the guard & Distance from & Men & Guns \\
\hline 1 & Station & Kengtung & 100 & 50 \\
2 & Bayet & 2 night journey & 50 & 25 \\
3 & Mong He & 2 night journey & 200 & 100 \\
4 & Win Lu WunKat & 3 night journey & 200 & 100 \\
5 & Mong Bat & 3 night journey & 50 & 25 \\
6 & Mong Chit & 4 night journey & 50 & 25 \\
7 & Chi Lake & 8 night journey & 50 & 25 \\
\hline
\end{tabular}

Source: Than Tun. 2004. Nal Hlai Yazawin (Collecting historical data from different lands), Yangon: Pyi Zone Publishing House: 25.

Table 3 List of men from the east of the Thanlwin River 1827-1828.

\begin{tabular}{llllllll}
\hline & No. & Gun man & Lance man & All two & Gun powder & Lead & Flint \\
\hline Kengtung & 1 & 1,250 & 1,250 & 2,500 & 1,250 & 1,250 & 5,000 \\
Keng Hung & 1 & 1,250 & 1,250 & 2,500 & 1,250 & 1,250 & 5,000 \\
Mong Li Gyi & 1 & 375 & 375 & 750 & 375 & 375 & 750 \\
Keng Chen & 1 & 200 & 200 & 400 & 200 & 200 & 400 \\
Mong Nyaung & 1 & 75 & 75 & 150 & 75 & 75 & 150 \\
Total & 5 & 3,150 & 3,150 & 6,300 & 3,150 & 3,150 & 11,300 \\
\hline
\end{tabular}

Source: List of Men Etc. From Chiefs on the East of the Thanlwin River 1827-1828, Parabaik Manuscript, MS, U Maung Maung Tin Collection.

Thanlwin River, a Burmese general was appointed as a Commander of Mong Nai Forces [4]. He was given duties to investigate all matters happening there and report all the situations. He was instructed to paid attention to the military affairs of those areas and to take action immediately for the security of those areas. He was supported with strong armed men and horses. And they were scattered in stages from the capital city to the trans-Thanlwin areas (Tables 4-6) [4].

The Royal Order of 25 August 1850 stated that the people lived in Keng Hung had abandoned their homes due to marauders and they had taken refuge in adjoining places of Kengtung, Keng Chiang, Mong Lin Gyi and Mong Nyaung (Mong Yawng). They all were allowed to return to their lands by their own free will. The King also ordered to the authorities at the said places that they should do nothing against the refugees if they decided to go back to their native places [4].

A Royal Order was passed on 14 October 1858 to restore law and order in Kengtung. A Burmese general from Mong Nai Troops was sent there [27]. The Myanmar garrison in Kengtung was never large and Myanmar's control and authority were only nominal, quite different from those in the Cis-Salween (Thanlwin) States which were nearer to the centre. In order to control over the trans-Thanlwin areas, Myanmar garrisons were also posted on the east of the Thanlwin River (Table 7) [1].

Early in 1889, the British Government anxiously considered the question of the frontier line which was to limit her responsibilities eastward. Kengtung and Keng Hung held or claimed to hold territory east of the Mekong [2]. Kengtung could not stand alone. China and Thailand might be invited to absorb them. Looking to the character of the country lying between the Thanlwin and Mekong, it was certain to be the refuge of all the discontent and outlawry of Myanmar [2].

During the last war between the English and Myanmar, the Chinese Emperor placed 300,000 men at Maingmawgyi to guard the Chinese frontier. The Chinese officials wrote to the Sawbwas inviting them 
to a conference at Maingmawgyi to draw up a friendly treaty, as the Myanmar King had been taken away by the English [2]. The Chiefs of Shan country replied that they would enter into friendly relations with the Government of one country if which side could confer on them peace and happiness [2].

Table 4 Stages on Ava-Mong Nai route.

\begin{tabular}{llllll}
\hline & Stage & Distance & Horses & Men & Township \\
\hline Ava to Singaing & 1 & 7 & 2 & 2 & Makkhara \\
Singaing to Hanpyinbo & 1 & 7 & 2 & 2 & Myinzaing \\
Hanpyinbo to Yakhine & 1 & 6 & 2 & 2 & Myingontaing \\
Yakhine to Khinle & 1 & 6 & 2 & 2 & Sawhla \\
Khinle to Ywangan & 1 & 6 & 2 & 2 & Kyiwun Wunzu \\
Ywangan to Kyaukku & 1 & 7 & 2 & 2 & Ngwegoonwun Wunzu \\
Kyaukku to Pwelha & 1 & 7 & 2 & 2 & Kyiwun Wunzu \\
Pwelha to Yawnghwe & 1 & 8 & 2 & 2 & Yawnghwe \\
Yawnghwe to Nanhkup & 1 & 7 & 2 & 2 & Nanhkup \\
Nanhkup to Nabham & 1 & 5 & 2 & 2 & Nanhkup \\
Nabham to Poonchaung & 1 & 5 & 2 & 2 & Mong Pwan \\
Poonchaung to Lwehkon & 1 & 6 & 2 & 2 & Mong Pwan \\
Lwehkon to Khinlu & 1 & 7 & 2 & 2 & Mong Nai \\
Khinlu to Mong Nai & 1 & 3 & 2 & 2 & Mong Nai \\
Total & 14 & 87 & 28 & 28 & \\
\hline
\end{tabular}

Distance is given in Tine ( 1 Tine $=2$ Miles $)$; 87 Tines $=174$ Miles.

Souce: Lists of Stages on Ava-Mong Nai Route, Parabaik Manuscript, MS, U Maung Maung Tin Collection.

Table 5 Stages on Mong Nai-Kengtung.

\begin{tabular}{llllll}
\hline & Stage & Distance & Horses & Men & Township \\
\hline Mong Nai to Non Poot & 1 & 7 & 2 & 2 & Mong Nai \\
Non Poot to Pan Lwe & 1 & 8 & 2 & 2 & Mong Nai \\
Pan Lwe to Hko Oak & 1 & 7 & 2 & 2 & Mong Nai \\
Hko Oak to Ha Le & 1 & 8 & 2 & 2 & Mong Nai \\
Ha Leto Se Gaw & 1 & 8 & 2 & 2 & Keng Hkang \\
Se Gaw to Keng Loon & 1 & 8 & 2 & 2 & Mong Nai \\
Keng Loon to Kali & 1 & 8 & 2 & 2 & Hsenwi \\
Kali to Hsenyut Granery & 1 & 3 & 2 & 2 & Ngwe Goon Wun Wunzu \\
Hsenyut Granery to Nyaung Ko Bin & 1 & 7 & 2 & 2 & Ngwe Goon Wun Wunzu(in the Forest) \\
Nyaung Ko Bin to Kin Moon Gyon & 1 & 7 & 2 & 2 & Ngwe Goon Wun Wunzu (in the Forest) \\
Kin Moon Gyon to Nan Kan & 1 & 8 & 2 & 2 & Hse Moung (in the Forest) \\
Nan Kan to Ohn Ape & 1 & 7 & 2 & 2 & Mong Hpi (in the Forest) \\
Ohn Ape to Mong Hpi & 1 & 8 & 2 & 2 & Kengtung \\
Mong Hpi to Kin Kwe & 1 & 7 & 2 & 2 & Kengtung (in the Forest) \\
Lom Kwe to Shwe Khya Nyaung Bin & 1 & 7 & 2 & 2 & Kengtung(in the Forest) \\
Shwe Khya Nyaung Bin to Htiyu Taung & 1 & 7 & 2 & 2 & Kengtung (in the Forest) \\
Hitiyu Taung to Kengtung & 1 & 7 & 2 & 2 & Kengtung \\
Total & 17 & 122 & 34 & 34 & \\
\hline Distang & & & & &
\end{tabular}

Distance is given in Tine $(1$ Tine $=2$ Miles); 122 Tines $=244$ Miles.

Souce: Lists of Stages on Mong Nai-Kengtung, Parabaik Manuscript, MS, U Maung Maung Tin Collection. 
Table 6 Stages on Kengtung-Keng Hung route.

\begin{tabular}{llllll}
\hline & Stage & Distance & Horses & Men & Township \\
\hline Kengtung to Hke Htway & 1 & 8 & 2 & 2 & Kengtung \\
Hke Htway to Mongma & 1 & 5 & 2 & 2 & Kengtung \\
Mongma to Htalaw & 1 & 5 & 2 & 2 & Kengtung \\
Htalaw to Mong Pang & 1 & 5 & 2 & 2 & Kengtung \\
Mong Pang to Mong Hseng & 1 & 7 & 2 & 2 & Kengtung \\
Mong Hseng to Mong He & 1 & 6 & 2 & 2 & Kengtung \\
Mong He to Mong Hson & 1 & 7 & 2 & 2 & Kengtung \\
Mong Hson to Keng Hung & 1 & 4 & 2 & 2 & Kengtung \\
Total & 8 & 47 & 16 & 16 & 47 Tines $=94$ Miles \\
Grand Total & 39 & 256 & 78 & 78 & 256 Tines $=512$ Miles \\
\hline
\end{tabular}

Source: Lists of Stages on Kengtung-Keng Hung Route Parabaik Manuscript, MS, U Maung Maung Tin Collection.

Table 7 Garrisons on the East of Thanlwin River.

\begin{tabular}{|c|c|c|c|c|c|c|c|c|}
\hline Keng Hung & Number & Man & Gun & Lance & All two & Gunpowder & Lead & Flint \\
\hline $\begin{array}{l}\text { Pin Twi Kin, U Noe Garrison, 14-day journey, } \\
\text { south east of Keng Hung }\end{array}$ & 1 & 100 & 60 & 40 & 100 & 60 & 60 & 180 \\
\hline U Tike, 10-day journey, south of Keng Hung & 1 & 60 & 40 & 20 & 60 & 40 & 40 & 120 \\
\hline $\begin{array}{l}\text { Lwe Kit Kin, Mong La Garrison, 9-day journey, } \\
\text { south of Keng Hung }\end{array}$ & 1 & 100 & 60 & 40 & 100 & 60 & 60 & 180 \\
\hline $\begin{array}{l}\text { U Kan Kin, Mong Pan Garrison, } 9 \text { day journey, } \\
\text { south of Keng Hung }\end{array}$ & 1 & 60 & 40 & 20 & 60 & 40 & 40 & 120 \\
\hline $\begin{array}{l}\text { Mong Yaw Kin, Mong Bon Garrison, 9-day journey, } \\
\text { south of Keng Hung }\end{array}$ & 1 & 100 & 60 & 40 & 100 & 60 & 60 & 180 \\
\hline $\begin{array}{l}\text { Pin Pet Kin, Mong Tong Garrison, 7-day journey, } \\
\text { south of Keng Hung }\end{array}$ & 1 & 60 & 40 & 20 & 60 & 40 & 40 & 120 \\
\hline $\begin{array}{l}\text { Kywe Sit Kin, Mong Ming Garrison, 6-day journey, } \\
\text { south of Keng Hung }\end{array}$ & 1 & 60 & 40 & 20 & 60 & 40 & 40 & 120 \\
\hline Total & 7 & 540 & 340 & 200 & 540 & 340 & 340 & 1,020 \\
\hline \multicolumn{9}{|l|}{ Keng Khung Ban Yu } \\
\hline Hotu Kin & 1 & 20 & 10 & 10 & 20 & 10 & 10 & 20 \\
\hline Pa Hka & 1 & 20 & 10 & 10 & 20 & 10 & 10 & 20 \\
\hline Hkut Long & 1 & 20 & 10 & 10 & 20 & 10 & 10 & 20 \\
\hline Tha The Mun Kin & 1 & 20 & 10 & 10 & 20 & 10 & 10 & 20 \\
\hline Total & 4 & 80 & 40 & 40 & 80 & 40 & 40 & 80 \\
\hline \multicolumn{9}{|l|}{ Mong Nyaw } \\
\hline Mong Lwe Mongwa Kin & 1 & 20 & 10 & 10 & 20 & 10 & 10 & 20 \\
\hline Ban Kwin Kin & 1 & 20 & 10 & 10 & 20 & 10 & 10 & 20 \\
\hline Athet Lan Kin & 1 & 20 & 10 & 10 & 20 & 10 & 10 & 20 \\
\hline Total & 3 & 60 & 30 & 30 & 60 & 30 & 30 & 60 \\
\hline \multicolumn{9}{|l|}{ Kengtung } \\
\hline Ba Yet Kin, 2-night journey from Kengtung & 1 & 100 & 50 & 50 & 100 & 50 & 50 & 150 \\
\hline Mong He Kin, 3-night journey from Kengtung & 1 & 50 & 25 & 25 & 50 & 50 & 25 & 75 \\
\hline Win Lu Win Kin, 3-night journey from Kengtung & 1 & 200 & 100 & 100 & 200 & 100 & 100 & 300 \\
\hline Mong But Kin, 3-night journey from Kengtung & 1 & 200 & 100 & 100 & 200 & 100 & 100 & 300 \\
\hline Mong Kyit Kin, 4-night journey from Mong But Kin & 1 & 50 & 25 & 25 & 50 & 25 & 25 & 75 \\
\hline Khyi Leik Tha, 8-night jorney from Mong But Kin & 1 & 50 & 25 & 25 & 50 & 25 & 25 & 75 \\
\hline Kyine Thi Kin, 8-night journey from Mong But Kin & 1 & 50 & 25 & 25 & 50 & 25 & 25 & 75 \\
\hline Total & 7 & 700 & 350 & 350 & 700 & 375 & 350 & 1,050 \\
\hline
\end{tabular}


Table 7 to be continued

\begin{tabular}{|c|c|c|c|c|c|c|c|c|}
\hline Mong $\mathrm{Pu}$ & & & & & & & & \\
\hline Me Wa Kin Tut & 1 & 50 & 25 & 25 & 50 & 25 & 25 & 75 \\
\hline Thabyu Bin Kin Tut & 1 & 25 & 13 & 12 & 25 & 13 & 13 & 39 \\
\hline Tapedara Kin Tut & 1 & 50 & 25 & 25 & 50 & 25 & 25 & 75 \\
\hline Total & 3 & 125 & 63 & 62 & 125 & 63 & 63 & 189 \\
\hline \multicolumn{9}{|l|}{ Summery } \\
\hline Keng Hung Garrison & 7 & 540 & 340 & 200 & 540 & 340 & 340 & 1,020 \\
\hline Keng Khyine Garrison & 4 & 80 & 40 & 40 & 80 & 40 & 40 & 80 \\
\hline Mong Nyaung Garrison & 3 & 60 & 30 & 30 & 60 & 30 & 30 & 60 \\
\hline Kengtung Garrison & 7 & 700 & 350 & 350 & 700 & 350 & 350 & 1050 \\
\hline Mong Pu Garrison & 3 & 125 & 63 & 62 & 125 & 63 & 63 & 189 \\
\hline Total & 24 & 1.505 & 823 & 682 & 1,505 & 823 & 823 & 2,399 \\
\hline
\end{tabular}

Souce: Lists of Garrisons on the East of Thanlwin River, Parabaik Manuscript, MS, U Maung Maung Tin Collection.

\subsection{The Relationship between Myanmar Kings and the Sawbwas of Kengtung}

Relations between the Chief and the Court of Ava (Inwa) were usually cordial. A money tribute was never exacted. The Sawbwas sent the yearly homage offerings to the Myanmar Kings. In return, the great valuable presents were regularly sent by the Myanmar Kings. Presents, other than the customary tribute, seem to have been sent down, and members of the ruling family who were summoned, or went to the Court were well treated. So long as the homage presents were regularly despatched, the authority of the King duly acknowledged and order preserved in the State, the Supreme Government was satisfied [10]. The Sawbwas sent yearly homage offerings to the Myanmar Kings on 1st waning moon of Thidinkyut (in October) [28].

The cordial relationship hadbeen achieved between Myanmar King and the Kengtung Sawbwa through the presenting of the daughters of subordinate Chiefs to the King as a bride. It is a mean of good relations. On 16 November 1562, the Sawbwa of Kengtung sent his daughter to the Myanmar King. The King also awarded to the Swabwa of Kengtung with white royal umbrella including five royal regalias. In 1588, Kengtung Chief sent his daughter to the Myanmar official at Keng Saeng from whom he received a return present of ten elephants [10].
When Myanmar forces advanced to Kengtung in January 1622 to suppress the rebel Sawbwa of Mong Nai, Kengtung Sawbwa paid homage his alligence and presented his daughter to Myanmar King [16]. A princess from Kengtung had been in the capital in 1622 [15]. Good relationship between Myanmar King and the Sawbwa of Kengtung had not been reached in 1707 as the Sawbwaof Kengtung (Sao Hsam Hpi,1702-1708) did not present his daughter to the King [15]. In 1841, Kengtung Sawbwa presented his daughter to the Myanmar King [26]. Myanmar King also sent his younger sister named Yadana Dawi to Kengtung Sawbwa (Sao Sai) in 1853 [3]. And thus good relationship had been established mutually between King and subordinate. In 1878, the Sawbwa sent the yearly homage to Myanmar King. Valuable return presents were given for the Sawbwa of Kengtung by Myanmar King [19]. Kengtung Sawbwa sent such homage as golden flower, silver flower, and many precious things to Myanmar King [19].

\section{Materials and Methods}

Both theory and practice were combined to achieve research goal. The authentic documents were taken from ancient historical sites in surrounding Kengtung town area. Author had studied Kengtung history throughout the last academic year 2016. Reliable historical source materials were used for the paper. 
Thorough investigation and cross checking method were used. The documents were examined based on the field studies. Author approaches to reach a creative thinking. Author's historical paper is expected to acquire a combination of the concept of learning, preparing, thinking and writing and so on.

\section{Results}

Many valuable historical heritages concerning social, culture, architecture and political treasures are hidden in the ancient city. One can open the door of a treasure house to keep in touch with the said heritages. The Chiefs of the town were entrusted with an autonomous power to rule over their subjects with justice. They had the right of possessing four Royal white umbrellas. The Royal sashes with fifteen rings and a necklace decorated with rubies in the middle and precious stones in the fringe were offered them in accordance with their grade. The Royal title of "raja" (the King) was offered them with the suffix of their Royal title, for example the Royal title of Thiri Pavara Maha Dhamma-raja. In it the last word raja means King in Pali literature. They all were vested an autonomous power like a King.

\section{Discussion}

Geopolitically Kengtung region was located in a most strategic place in Myanmar. It shares borders with China on the north and Thailand on the east. It makes a critical point of Myanmar's defences. Besides Kengtung supported contigents for Myanmar Kings to control the eastern regions of the Thanlwin River. In order to maintain peace and security of the Myanmar's areas, many guard stations were placed from the capital city to Kengtung and Mong Nai. Kengtung forces stood on the side of Myanmar in wars with Thailand and Chieng Mai. Kengtung came in the first class, and was the most important of the Myanmar's possessions east of the Thanlwin River. Its position may be roughly judged by the tribute paid to the King and the contigent it was bound to supply to the royal army. Therefore Kengtung was very important for the security of Myanmar's eastern frontier during the Konbaung period.

In Myanmar, chronicle Kengtung was referred to be "Taing" (Province). It was a town including nine towns prefix with "Keng" at the initiate of the town's name.It is an ancient walled city town and it is 198 years aged old city in 2017 . It will be 200 years old in coming 2019. The anniversary day of the 200 years aged old city will fall in coming 2019. The city passed over four times of golden jubilee. The town was full of richness in cultural heritages together with its good historical background. The Chiefs of the town had maintained the integrity and the sovereignty of Myanmar Kingdom.

\section{Finding}

Kengtung was one of the biggest Trans-Salween (Thanlwin) States and it was recognized by Ava (Inwa) as one of the premier Shan States. Kengtung played an important role in maintaining the security of Myanmar's eastern frontier and it was very prominent in the time of Konbaung Kings to defend from the aggression of neighbouring countries like China and Thailand. For security reason, Konbaung Kings paid attention to the frontier towns which was close to China and Thailand. In 1852, Thailand invaded Kengtung. But Myanmar forces strongly defended and repulsed the foreign foe. This event was stated in Yodaya Naing Mawgun, Victory over Thailand, which was recorded in the sacred Myanmar Literature called Mawgun written by U Ponnya. Moreover the relationship between Kengtung Sawbwa and the Myanmar Kings was very prominent in Myanmr History. The ethnics of Myanmar and Shan joined hands with each other and repulsed any invasions of the neighbouring countries of Myanmar.

\section{Conclusion}

Kengtung (Kyaing Tong in Burmese term) is one of the ancient cities in Myanmar. According to the reliable historical source material, it was founded as a 
state by King Mang Rai (1259-1317) of Chiang Rai in northern Thailand. He first came to Kengtung in 1230 AD. The present walled city of Kengtung was renovated by Sao Maha Hkanan in 1819. The wall was completed in 1833 . The present city was lasted for two centuries. The exact age of the walled city is 197 years old in 2016. In coming 2019, it will be 200 years old. The anniversary day of the 200 years aged-old walled city will fall in coming 2019. Nearly one third of the city walls are still left in present day. Some city walls facing south, near Buddha Foot Print Pagoda, are not ruined and they evidently show the height of the walls and their thickness. The city walls lying through from the city gate of Ngarm Hpat to Hpar Yang city gate are not ruined. Kengtung walled city was built like a conch in shape as a token of full of auspicious fall into the town.

Kengtung was one of the towns among the nine towns which began with the prefix of "Keng". In another word, Kengtung was included in the nine Shan towns of Keng in the Shan State. The Sawbwa was vested autonomous power components with royal regalias. He was a sole ruler having possessed four royal white umbrellas offered by Myanmar King.

Kengtung is a very prominent town in the easternmost part of Myanmar together with their multi-national races. It is one of the significant states in Myanmar history. In monarchical time, the state was administered by own chiefs. Most sawbwas and most of the more important myosas have their titles suffixed with the word raja or yaza, while the King suffixed his with rajadhiraja (King of Kings). Very often the Shan Sawbwas were referred to as newin bayin (sun-set king) while the king was nedwet bayin (sun-rise king), for obvious reasons. Sawbwas would be summoned to attend the coronation ceremony of a new king and the annual kadaw pwe (Paying Homage Ceremony) at the capital.

\section{Acknowledgement}

Author would like to express my thanks to the
Editorial Office for having opportunity to include my research paper in the Journal of Environmental Science and Engineering.

\section{References}

[1] Mangrai, Sao Saimong. 1965. The Shan States and the British Annexation, No.57. Data Paper, Southeast Asia Program, Ithaca, Department of Asian Studies, New York: Cornell University: 63, 103.

[2] Crosthwaite, Sir Charles. 1968. The Pacification of Burma, London: Frank Cass and Company Limited: 136-37, 143, 210, 212-13.

[3] Than Tun. 2004. Nal Hlai Yazawin (Collecting historical data from different lands), Yangon: Pyi Zone Publishing House: 26-27, 31, 41-3, 50, 56-7.

[4] Than Tun, Dr. 1988. The Royal Orders of Burma, A.D.1598-1885, Part. 8. AD. 1819-1853, Kyoto: The Center for Southeast Asian Studies, Kyoto University:145, 192-3, 286, 543.

[5] Furnival, J. S., and Pe Maung Tin. 1960. Jambudipa Ok Saung Kyan (The Crown of Jambudipa), Yangon: Burma Research Society: 13.

[6] Sai Kam Mong. 2004. The History and Development of the Shan Scripts, Chiang Mai: Silkworm Books: 16-17.

[7] Mi Mi Khaing, Kambawsa: A Modern Review, Paper, no date: 5 .

[8] Shan Swe. 1969. Chronicle of Kengtung Town, Vol. 16. No. 12. The Guardian, Burma's National Magazine: $39-42$.

[9] Shan Swe. 1970. Chronicle of Kengtung Town, Vol. 17. No. 4. The Guardian, Burma's National Magazine: 26-27.

[10] Scott, J. George., and Hardiman, J. P. 1901. Gazetteer of Upper Burma and The Shan State, Part. 2. Vol.1. Rangoon: Superintendent Government Printing:402, 405, 407-08, 410-11, 416-17, 429, 432-3, 442, 444, 446-7.

[11] Field Studies.

[12] List of Chiefs and Leading Families in the Shan States and Karenni. 1943. Simla: Government of India Press: 5, 6.

[13] Tun Nyo, Twin Thin Taik Wun Maha Sithu U. 2007. Maha Yazawun Thit (New Great Chronicle), Taungoo Period, Yangon: Aar Mangthit Sarpay (New Strength Book Shop): 102.

[14] Hmannan Maha Yazawundawgyi (Glass Palace Chronicle), 1993. Vol. 2. Yangon: New Light of Myanmar and The Guardian Press: 321-22,401.

[15] Hmannan Maha Yazawindawgyi (Glass Palace Chronicle), 1967. Vol. 3. Yangon: Pyigyi Mandaing Pitaka Press: 179, 184-5, 342 . 
[16] Than Tun, Dr. 1983. The Royal Orders of Burma, A.D. 1598-1885, Part. 1. A.D. 1598-1684, Kyoto: The Center for Southeast Asian Studies, Kyoto University: 13, 301.

[17] Than Tun, Dr. 1985. The Royal Orders of Burma, A.D. 1598-1885, Part. 3. A.D. 1751-1781, Kyoto: The Center for Southeast Asian Studies, Kyoto University: xxvii.

[18] Scott, J. George., and Hardiman, J. P. 1900. Gazetteer of Upper Burma and The Shan State, Part. 1. Vol. 1. Rangoon: Superintendent Government Printing: 291.

[19] Taw Sein Kho, Kyauk-sar Wun Minister. 1977. Hluttaw Hmattan (Records of the Hluttaw), edited by Aung Thein, U. Yangon: Ministry of Culture: 142, 145-6, 173-4, 181-2.

[20] Than Tun, Dr. 1986. The Royal Orders of Burma, A.D. 1598-1885, Part. 5. A.D. 1788-1806, Kyoto: The Center for Southeast Asian Studies, Kyoto University: 29, 31, 36-7, 102, 308.

[21] Than Tun, Dr. 1988. The Royal Orders of Burma, A.D. 1598-1885, Part. 7. AD. 1811-1819, Kyoto: The Center for Southeast Asian Studies, Kyoto University: 58.

[22] Than Tun, Dr. 1990. The Royal Orders of Burma, A.D.
1598-1885, Part. 10. Epiloge, Glossary and Index, Kyoto: The Center for Southeast Asian Studies, Kyoto University: 63, 68 .

[23] Myanmar Encyclopedia. 1970. Vol. 2. Yangon: Sarpay Beikman Press: 389-390.

[24] Maung Maung Tin, U. 2004. Konbaungset Mahayazawindawgyi (History of the Konbaung Dynasty), Vol. 2. Yangon: Yarpyi Book Shop: 52.

[25] Than Tun, Dr. 1987. The Royal Orders of Burma, A.D. 1598-1885, Part. 6. A.D. 1807-1810, Kyoto: The Center for Southeast Asian Studies, Kyoto University: 14.

[26] Maung Maung Tin, U. 2004. Konbaungset Mahayazawindawgyi (History of the Konbaung Dynasty), Vol. 3. Yangon: Yarpyi Book Shop: 23,73-4.

[27] Than Tun, Dr. 1989. The Royal Orders of Burma AD. 1598-1885, Part. 9. A.D. 1853-1885, Kyoto: The Center for Southeast Asian Studies, Kyoto University: 87-8.

[28] Thiri Uzana, Inyonywasar Wungyi. 2001. Loka Byuhar Kyan (Treatise on the affairs of Kings) (Inyon Sardan) Yangon:Ministry of Culture:49. 